Article

\title{
Effects of Phytonutrients on Ruminal Fermentation, Digestibility, and Microorganisms in Swamp Buffaloes
}

\author{
Thiwakorn Ampapon ${ }^{1}\left(\mathbb{D}\right.$, Kampanat Phesatcha ${ }^{2}$ and Metha Wanapat ${ }^{1, *}$ \\ 1 Tropical Feed Resources Research and Development Center (TROFREC), Department of Animal Science, \\ Faculty of Agriculture, Khon Kaen University, Khon Kaen 40002, Thailand \\ 2 Department of Animal Science, Faculty of Agriculture and Technology, Nakhon Phanom University, \\ Nakhon Phanom 48000, Thailand \\ * Correspondence: metha@kku.ac.th; Tel.: +66-81-9324180
}

Received: 30 May 2019; Accepted: 1 July 2019; Published: 11 September 2019

check for updates

Simple Summary: Fermentation in ruminants can influence greenhouse gas production, especially methane $\left(\mathrm{CH}_{4}\right)$ production. Phytonutrients (PTN) and secondary metabolites (tannins, saponins) have antimicrobial activity which can be used for the inhibition of rumen methanogens and the reduction of methane emissions in ruminants. The aim of the present study was to investigate the influence of PTN containing both mangosteen peel powder and banana flower powder on feed consumption, nutrient digestibility, and rumen microorganisms in swamp buffaloes. The results suggest that supplementation of PTN can improve fiber digestibility, increase the proteolytic and cellulolytic bacteria, and alter rumen volatile fatty acids (VFAs), especially increased $C_{3}$ and reduced methane production. This study shows that PTN containing either mangosteen peel powder (MSP) or banana flower powder (BFP) could be used as a rumen modifier.

\begin{abstract}
This experiment aimed to use dietary sources containing phytonutrients (PTN) such as mangosteen peel powder (MSP) and banana flower powder (BFP) as sources of phytonutrients. Four swamp buffalo bulls fitted with rumen fistulae were used as experimental animals. A digestion trial covering four periods was used according to a $4 \times 4$ Latin square design with four treatments: Treatment $1(\mathrm{~T} 1)=$ control $($ Cont $), \mathrm{T} 2=$ supplementation of PTN1 fed at $100 \mathrm{~g} / \mathrm{d}, \mathrm{T} 3=$ supplementation of PTN2 fed at $100 \mathrm{~g} / \mathrm{d}$, and T4 = supplementation of PTN3 fed at $100 \mathrm{~g} / \mathrm{d}$. The experiment was conducted for four periods; each period lasted for 21 days. All animals were fed a concentrate mixture at $0.5 \%$ body weight, while rice straw, water, and mineral blocks were fed ad libitum. The findings revealed significant increases in the digestibility of neutral detergent fiber (NDF) and acid detergent fiber (ADF), while no changes in dry matter feed consumption occurred due to PTN supplementation. Rumen fermentation end-products, such as total volatile fatty acids (TVFA), propionic acid $\left(\mathrm{C}_{3}\right)$, and butyric acid $\left(\mathrm{C}_{4}\right)$, were notably enhanced $(p<0.05)$ and there were the highest in PTN2 and PTN3, whilst acetic acid $\left(\mathrm{C}_{2}\right)$ was significantly decreased with PTN supplementation groups. Furthermore, the rumen protozoal population was suppressed $(p<0.05)$, which resulted in decreased rumen methane production $(p<0.05)$, while the bacterial population was enhanced. Using PTN sources can improve rumen fermentation as well as mitigating rumen methane production.
\end{abstract}

Keywords: rumen enhancer; phytonutrients; fruit waste; greenhouse gas

\section{Introduction}

There are many factors that could alter rumen ecology, for example, a high grain and low fiber diet can reduce rumen $\mathrm{pH}$. Feed additives like antibiotics or chemicals and buffers can improve 
rumen fermentation efficiency [1]. Research and development regarding methane $\left(\mathrm{CH}_{4}\right)$ production in ruminants has received considerable attention in which mitigation of the rumen $\mathrm{CH}_{4}$ has been the main issue [2,3]. $\mathrm{CH}_{4}$ production from rumen fermentation can result in a loss of energy intake of about $8-12 \%$ in ruminants [4]. Phytonutrients or secondary metabolites (tannins, saponins, essential oils, etc.) impose antimicrobial activity which can be used for the inhibition of specific microorganism groups in the rumen and can modify their fermentation [5,6]. Poungchompu et al. [7] and Shokryzadan et al. [8] stated that mangosteen (Garcinia mangostana) peel is one kind of agricultural by-product containing the highest levels of condensed tannins (CT) and saponins (SP) when compared with other tropical plants and fruit peels. It is a non-chemical feed additive that is used as a rumen fermentation modifier, and it mitigates methane production. Phytonutrients have been shown to affect ruminal fermentation efficiency, especially by decreasing the acetic acid $\left(C_{2}\right)$ concentration, reducing ruminal protozoa and the methanogen population, and mitigating $\mathrm{CH}_{4}$ emissions [9]. Furthermore, Wanapat et al. [10] reported that consumption of dietary mangosteen peel powder (MSP) by buffaloes can increase the concentration of $C_{3}$ and microbial protein synthesis. In addition, Oskoueian et al. [11] found that flavonoids, especially naringin and quercetin, suppressed the protozoal population and methanogen population in an in vitro experiment.

Banana (Musa sapientum L.) flower powder (BFP) has been reported to be used as a rumen buffering agent, as it contains a high concentration of mineral elements. The $\mathrm{pH}$ stability in the rumen is considered a prime factor that feeds into optimal rumen ecology, as the shift towards acidic conditions, especially $\mathrm{pH}$ values lower than 6.0, will dramatically affect microorganisms and the fermentation process $[1,12]$. Dietary sources containing phytonutrients (PTN) have been used to replace chemical buffers and have resulted in improved rumen fermentation, as shown by Poungchonpu et al. [7], Norrapoke et al. [13], Foiklang et al. [14], and Kang et al. [15,16]. However, the use of other PTN in combination, especially in swamp buffaloes, has not been fully investigated. Therefore, this experiment aimed to investigate the influence of PTN containing both mangosteen peel powder and banana flower powder on feed consumption, nutrient digestibility, and rumen microorganisms in swamp buffaloes fed rice straw as a basal roughage.

\section{Materials and Methods}

\subsection{Feeds, Animals, and Experimental Design}

The sources of phytonutrients were as follows: The mangosteen peel (MSP) was collected from fresh fruit, sun-dried for 3 to 4 days, and ground into powder form. The banana flower powder (BFP) was collected from fresh flowers, sun-dried for 5 to 6 days, and ground into powder form. Mangosteen peel powder, banana flower powder, urea, and sulfur were mixed to form PTN1, PTN2, and PTN3, as reported in Table 1. The concentrate contained 14.5\% of crude protein. Feed ingredients and chemical compositions are presented in Table 1.

The study was conducted at the Tropical Feed Resources Research and Development Center (TROFREC), Department of Animal Science, Faculty of Agriculture, Khon Kaen University (KKU), Thailand. All procedures involving animals in the metabolism studies were approved by the Institutional Animal Care and Use Committee of Khon Kaen University (KKU) (ref. no. AEKKU 18/2558).

Four swamp buffalo bulls fitted with rumen fistulae were used as experimental animals. A digestion trial covering four periods was used in a $4 \times 4$ Latin square design with four treatments: Treatmeat 1 $(\mathrm{T} 1)=$ control (Cont), T2 = supplementation of PTN1 fed at $100 \mathrm{~g} / \mathrm{d}, \mathrm{T} 3=$ supplementation of PTN2 fed at $100 \mathrm{~g} / \mathrm{d}$, and T4 = supplementation of PTN3 fed at $100 \mathrm{~g} / \mathrm{d}$. The experiment was conducted for 4 periods, and each period lasted for 21 days. All animals were fed the concentrate mixture at $0.5 \%$ body weight, while the concentrate mixture was fed in the morning and afternoon (07:00 a.m., 16:30 p.m.). Rice straw was fed ad libitum. Water and mineral blocks were available at all times for all buffaloes. 
Table 1. Feed ingredients and chemical compositions of the experimental diets.

\begin{tabular}{cccccc}
\hline Item & Concentrate & PTN1 & PTN2 & PTN3 & Rice Straw \\
\hline Ingredients, g/kg dry matter & & & & & \\
Cassava chip & 618 & - & - & - & - \\
Rice bran & 78 & - & - & - & - \\
Coconut meal & 120 & - & - & - & - \\
Palm kernel meal & 120 & - & - & - & - \\
Mangosteen peel powder (MSP) & - & 910 & - & 455 & - \\
Banana flower powder (BFP) & - & - & 910 & 455 & - \\
Cassava chip meal & - & 50 & 50 & 50 & - \\
Molasses & 19 & - & - & - & - \\
Urea & 30 & 30 & 30 & 30 & - \\
Mineral mixture & 5 & - & - & - & - \\
Salt & 5 & - & - & - & - \\
Sulfur & 5 & 10 & 10 & 10 & - \\
Chemical composition, g/kg dry matter & & & & & \\
Dry matter, g/kg & 898 & 925 & 905 & 913 & 905 \\
Organic matter & 920 & 942 & 913 & 921 & 880 \\
Ash & 80 & 58 & 87 & 79 & 220 \\
Crude protein & 145 & 189 & 151 & 168 & 29 \\
Neutral detergent fiber & 265 & 557 & 677 & 611 & 795 \\
Acid detergent fiber & 124 & 495 & 451 & 475 & 436 \\
Condensed tannins & - & 167 & 113 & 145 & - \\
\hline
\end{tabular}

PTN1 (containing mangosteen peel powder at 91\%) at $100 \mathrm{~g} /$ head/day; PTN2 (containing banana flower powder at 91\%); PTN3 (containing mangosteen peel powder at $45.5 \%$ and banana flower powder at $45.5 \%$ ).

\subsection{Data Collection and Sample Analysis}

After the first 14 days, buffaloes had adapted to the diet, and feed consumption was measured. Samples of concentrate and rice straw including refusals were collected daily during the feeding period. During the last 7 days, all buffaloes were moved to the metabolism crates for feed, feces, and urine collection. Feed and fecal samples were measured for nutritive values of dry matter (DM), organic matter (OM), ash and crude protein (CP) [17] and neutral detergent fiber (NDF), acid detergent fiber (ADF), and acid detergent lignin (ADL) [18], and then nutrient digestibility was estimated according to the standard methods described by Wanapat et al. [19]. Condensed tannins (CT) were analyzed by the Vanillin-HCL method (Burns [20]; modified by Wanapat and Poungchompu [21]).

At the last day of each period, rumen fluid samples were collected at $0,2,4$, and $6 \mathrm{~h}$ post morning feeding. Rumen fluid was immediately measured for $\mathrm{pH}$ and temperature using a portable $\mathrm{pH}$ meter (HANNA Instrument HI 8424 microcomputer, Hanna Instruments (S) Pte Ltd., 161 Kallang Way, Singapore). Rumen fluid samples were then filtered through three layers of cheesecloth. The first part was used for the analysis of volatile fatty acids (VFA) and $\mathrm{NH}_{3}-\mathrm{N}$, where $5 \mathrm{~mL}$ of $\mathrm{H}_{2} \mathrm{SO}_{4}$ solution $(1 \mathrm{M})$ was added to $45 \mathrm{~mL}$ of rumen fluid. The mixture was centrifuged at $1600 \times \mathrm{g}$ for $15 \mathrm{~min}$, and the supernatant was stored at $-20^{\circ} \mathrm{C}$ prior to VFA analysis using high-performance liquid chromatography (HPLC) and the $\mathrm{NH}_{3}-\mathrm{N}$ analysis method [17]. The next part was used for the measurement of microbial populations by total direct counts of bacteria, protozoa, and fungal zoospores [22]. The last part was cultured for groups of bacteria (i.e., cellulolytic, proteolytic, amylolytic, and total viable bacterial counts) using the roll-tube technique [23]. A blood sample (about $10 \mathrm{~mL}$ ) was drawn from the jugular vein into EDTA-containing tubes and was separated by centrifugation at $500 \times \mathrm{g}$ for $10 \mathrm{~min}$ at $4{ }^{\circ} \mathrm{C}$ to obtain plasma. Then, the plasma was stored at $-20^{\circ} \mathrm{C}$ until the analysis of blood urea $\mathrm{N}$ according to the method of Crocker [24].

Rumen $\mathrm{CH}_{4}$ production was estimated using VFA proportions according to Moss et al. [25] and as follows:

$\mathrm{CH}_{4}$ production $=0.45\left(\right.$ acetate, $\left.\mathrm{C}_{2}\right)-0.275\left(\right.$ propionate, $\left.\mathrm{C}_{3}\right)+0.4\left(\right.$ butyrate, $\left.\mathrm{C}_{4}\right)$. 


\subsection{Statistical Analyses}

All data were statistically analyzed using the general linear-model procedure (Statistical Analysis System, SAS (2013) [26]) according a $4 \times 4$ Latin square design in which the buffalo, period, and level of PTN supplementation were the main factors. Treatment means were analyzed using the following model: Yijk $=\mu+T i+C j+R k+$ eijk, where Yijk is the criteria under study in treatment $i$, column $j$, and row $\mathrm{k} ; \mu$ is the overall sample mean; Ti is the effect of treatment $\mathrm{i}$; $\mathrm{Cj}$ is the effect of treatment $\mathrm{i}$ at column $\mathrm{j}$; Rk is the effect of treatment $\mathrm{i}$ at row $\mathrm{k}$; and eijk is the error.

\section{Results}

\subsection{Voluntary Feed Consumption and Digestibility}

In Table 2, rice straw intake was not influenced by PTN supplementation, and total DM feed intake was not significantly different among PTN supplementation groups. The apparent digestibility in terms of DM, OM and CP was not increased by PTN supplementation $(p>0.05)$. However, the PTN groups showed significantly enhanced digestibility of fiber (NDF, ADF). Although the values were the highest for the PTN2 and PTN3 groups, there were no significant difference among treatments.

Table 2. Effects of some sources of phytonutrients (PTN) on voluntary feed intake and nutrient digestibility in swamp buffaloes.

\begin{tabular}{ccccccc}
\hline Items & Cont & PTN1 & PTN2 & PTN3 & SEM & $p$-Value \\
\hline $\begin{array}{c}\text { Rice straw DM intake } \\
\text { kg/day }\end{array}$ & 6.8 & 6.7 & 6.9 & 6.9 & 0.20 & 0.87 \\
\%BW & 1.4 & 1.4 & 1.4 & 1.4 & 0.04 & 0.40 \\
$\begin{array}{c}\text { Concentrate DM intake } \\
\text { kg/day }\end{array}$ & 1.8 & 1.9 & 1.9 & 1.9 & 0.32 & 0.19 \\
$\begin{array}{c}\text { \%BW } \\
\text { Total DM intake }\end{array}$ & 0.5 & 0.5 & 0.5 & 0.5 & 0.07 & 0.61 \\
kg/day & & & & & & \\
\%BW & 8.6 & 8.8 & 8.8 & 8.9 & 0.13 & 0.56 \\
$\begin{array}{c}\text { Apparent digestibility, \%DM } \\
\text { Dry matter, \% }\end{array}$ & 1.9 & 1.9 & 1.9 & 1.9 & 0.25 & 0.47 \\
$\quad \begin{array}{l}\text { Organic matter } \\
\text { Crude protein }\end{array}$ & 59.0 & 58.5 & 57.9 & 58.7 & 1.56 & 0.45 \\
Neutral detergent fiber & 62.5 & 60.3 & 60.1 & 61.0 & 1.77 & 0.33 \\
Acid detergent fiber & $40.5^{\mathrm{a}}$ & $45.7^{\mathrm{b}}$ & $48.1^{\mathrm{b}}$ & $48.0^{\mathrm{b}}$ & 1.15 & 0.01 \\
\hline
\end{tabular}

$\overline{a, b, c}$ Means in the same row with different superscripts differ $(p<0.05)$; Cont (control group); PTN1 (containing mangosteen peel powder at $91 \%$ ) at $100 \mathrm{~g} / \mathrm{head} /$ day; PTN2 (containing banana flower powder at $91 \%$ ); PTN3 (containing mangosteen peel powder at $45.5 \%$ and banana flower powder at $45.5 \%$ ); SEM = standard error of the mean.

\subsection{Ruminal Fermentation, Blood, Methane Production}

The results for ruminal fermentation, blood, and methane production are presented in Table 3 . The $\mathrm{pH}(6.6-6.8)$ and temperature (38.8-39.5) in the rumen were unchanged $(p>0.05)$. The ruminal $\mathrm{NH}_{3}-\mathrm{N}$ concentration was increased in the PTN supplementation groups, while the blood urea nitrogen (BUN) concentration was similar among treatments. The total volatile fatty acid (TVFA), propionic acid $\left(C_{3}\right)$, and butyric acid $\left(C_{4}\right)$ concentrations increased $(p<0.05)$ following PTN supplementation, especially in the PTN2 and PTN3 groups, which had the highest concentrations. In contrast, the acetic acid $\left(C_{2}\right)$ concentration decreased $(p<0.05)$, while the $\mathrm{C}_{2}: \mathrm{C}_{3}$ ratio and estimated $\mathrm{CH}_{4}$ production decreased remarkably in the PTN supplementation groups, and was the lowest in PTN2. 
Table 3. Effects of some sources of phytonutrients (PTN) on the ruminal pH, temperature, ammonia nitrogen $\left(\mathrm{NH}_{3}-\mathrm{N}\right)$, blood urea nitrogen $(\mathrm{BUN})$, and volatile fatty acid concentrations in swamp buffaloes.

\begin{tabular}{|c|c|c|c|c|c|c|}
\hline \multirow{2}{*}{ Item } & \multicolumn{4}{|c|}{ Supplementation $(100 \mathrm{~g} / \mathrm{h} /$ day $)$} & \multirow{2}{*}{ SEM } & \multirow{2}{*}{$p$-Value } \\
\hline & Cont & PTN1 & PTN2 & PTN3 & & \\
\hline \multicolumn{7}{|l|}{ Rumen parameters } \\
\hline $\mathrm{pH}$ & 6.7 & 6.6 & 6.8 & 6.8 & 1.89 & 0.13 \\
\hline Temperature & 38.8 & 38.9 & 39.5 & 39.1 & 1.53 & 0.35 \\
\hline Ammonia nitrogen, $\mathrm{mg} / \mathrm{dL}$ & $12.1^{\mathrm{a}}$ & $15.7^{\mathrm{b}}$ & $14.0^{\mathrm{a}}$ & $14.9^{\mathrm{b}}$ & 0.60 & 0.01 \\
\hline Blood urea nitrogen, $\mathrm{mg} / \mathrm{dL}$ & 6.8 & 6.6 & 6.6 & 6.7 & 2.77 & 0.24 \\
\hline Total volatile fatty acid, $\mathrm{mmol} / \mathrm{L}$ & $97.2^{\mathrm{a}}$ & $101.0^{\mathrm{ab}}$ & $103.0^{\mathrm{b}}$ & $106.6^{b}$ & 1.71 & 0.04 \\
\hline Acetic acid $\left(\mathrm{C}_{2}\right), \%$ & $73.4^{\mathrm{a}}$ & $65.1^{\mathrm{b}}$ & $59.3^{c}$ & $64.0^{\mathrm{b}}$ & 1.12 & 0.01 \\
\hline Propionic acid $\left(\mathrm{C}_{3}\right), \%$ & $15.5^{\mathrm{a}}$ & $21.5^{\mathrm{b}}$ & $26.9^{c}$ & $22.5^{b}$ & 1.15 & 0.01 \\
\hline Butyric acid $\left(\mathrm{C}_{4}\right), \%$ & $11.1^{\mathrm{a}}$ & $13.0^{\mathrm{b}}$ & $14.9^{\mathrm{c}}$ & $13.6^{\mathrm{b}}$ & 0.41 & 0.02 \\
\hline $\mathrm{C}_{2}: \mathrm{C}_{3}$ & $4.8^{\mathrm{a}}$ & $3.2^{b}$ & $2.1^{\mathrm{c}}$ & $2.9^{b}$ & 0.57 & 0.01 \\
\hline Methane estimation, $\mathrm{mM} / \mathrm{L}$ * & $33.2^{\mathrm{a}}$ & $28.7^{\mathrm{b}}$ & $25.8^{\mathrm{c}}$ & $28.1^{b}$ & 0.83 & 0.03 \\
\hline
\end{tabular}

$\mathrm{a}, \mathrm{b}, \mathrm{c}$ Means in the same row with different superscripts differ $(p<0.05)$; Cont (control group); PTN1 (containing mangosteen peel powder at 91\%) at $100 \mathrm{~g} / \mathrm{head} /$ day; PTN2 (containing banana flower powder at 91\%); PTN3 (containing mangosteen peel powder at $45.5 \%$ and banana flower powder at $45.5 \%$ ); ${ }^{*}$ Calculated according to Moss et al. [25] $\mathrm{CH}_{4}$ production $=0.45$ (acetate) -0.275 (propionate) +0.4 (butyrate); $\mathrm{SEM}=$ standard error of the mean.

\subsection{Microbial Population Enumeration}

The protozoal population significantly decreased $(p<0.05)$ following PTN supplementation, while under PTN1 and PTN3 supplementations, the protozoal numbers remarkably decreased $(p<0.05)$. However, the concentrations of fungal zoospores, starch-digesting bacteria, and total bacteria were unchanged $(p>0.05)$ among treatments, while the rumen proteolytic and cellulolytic bacterial populations were the highest $(p<0.05)$ in the PTN2 and PTN3 supplementation groups (Table 4).

Table 4. Effects of some sources of phytonutrients (PTN) on the rumen protozoa, fungal zoospore, and bacteria populations in swamp buffaloes.

\begin{tabular}{ccccccc}
\hline \multirow{2}{*}{ Items } & \multicolumn{3}{c}{ Supplementation $(\mathbf{1 0 0} \mathrm{g} / \mathrm{h} / \mathbf{d a y})$} & \multirow{2}{*}{ SEM } & \multirow{2}{*}{$p$-Value } \\
\cline { 2 - 4 } & Cont & PTN1 & PTN2 & PTN3 & & \\
\hline Total direct counts & & & & & & \\
Protozoa, $\times 10^{5} \mathrm{cell} / \mathrm{mL}$ & $8.2^{\mathrm{a}}$ & $6.5^{\mathrm{b}}$ & $7.7^{\mathrm{c}}$ & $6.7^{\mathrm{b}}$ & 0.09 & 0.02 \\
Fungal zoospore, $\times 10^{5} \mathrm{cell} / \mathrm{mL}$ & 5.4 & 5.4 & 5.6 & 5.6 & 0.41 & 0.12 \\
Roll-tube technique, $\mathrm{CFU} / \mathrm{mL}$ & & & & & & \\
Amylolytic bacteria, $\times 10^{7}$ & 2.9 & $3.2^{\mathrm{n}}$ & 3.3 & 3.2 & 0.43 & 0.07 \\
Proteolytic bacteria, $\times 10^{7}$ & $3.5^{\mathrm{a}}$ & $4.2^{\mathrm{b}}$ & $4.4^{\mathrm{b}}$ & $4.4^{\mathrm{b}}$ & 0.15 & 0.02 \\
Cellulolytic bacteria, $\times 10^{8}$ & $3.4^{\mathrm{a}}$ & $3.5^{\mathrm{a}}$ & $4.6^{\mathrm{b}}$ & $4.1^{\mathrm{b}}$ & 0.16 & 0.01 \\
Total viable bacteria, $\times 10^{8}$ & 5.4 & 5.6 & 5.9 & 5.7 & 0.77 & 0.15 \\
\hline
\end{tabular}

$\overline{a, b, c}$ Means in the same row with different superscripts differ $(p<0.05)$; Cont (control group); PTN1 (containing mangosteen peel powder at $91 \%$ ) at $100 \mathrm{~g} / \mathrm{head} /$ day; PTN2 (containing banana flower powder at $91 \%$ ); PTN3 (containing mangosteen peel powder at $45.5 \%$ and banana flower powder at $45.5 \%$ ); SEM = standard error of the mean.

\section{Discussion}

\subsection{Voluntary Feed Consumption and Digestibility}

Supplementation of PTN did not affect feed consumption in this experiment. This is similar to the findings of Kang and Wanapat [27], who reported that supplementation of a banana flower powder (BFP)-pellet at $4 \%$ of dry matter intake (DMI) did not impact feed intake in dairy steers. The use of MSP at $30 \mathrm{~g} / \mathrm{d}$ did not impact feed consumption and nutrient digestibility in buffaloes [28], while the use of tannin sources as less than $50 \mathrm{~g} / \mathrm{kg}$ DM of feed did not suppress DMI or nutrient digestibility in beef 
cattle [29]. However, Cruywagen et al. [30] found that the use of bicarbonate as a buffering agent in a high concentrate diet did not alter dry matter feed intake. Moreover, the result from Rauch et al. [31] revealed that the use of sodium bicarbonate and calcium magnesium carbonate did not influence dry matter feed consumption but increased the digestibility of crude protein in lactating dairy cows. In this study, DM, OM and CP digestibility did not ultimately change, while NDF and ADF contrarily increased in the PTN2 and PTN3 groups. This phenomenon may be because BFP and CT reduce the protozoal number, and bacteria are the feed substrate of protozoa; hence, it would be expected that the fibrolytic bacteria population would subsequently increase. In addition, BFP supplementation improves the in vitro true digestibility, according to Kang and Wanapat [27]. Furthermore, rumen $\mathrm{pH}$ is the major factor influencing fibrolytic bacteria attachment in the particles of feed [32].

\subsection{Ruminal Fermentation, Blood, and Methane Production}

In this experiment, the $\mathrm{pH}$ and temperature in the rumen were not impacted and remained in the narrow range for ruminal fermentation of feeds [19,32]. Russell [33] stated the importance of $\mathrm{pH}$ on propionate production in the rumen; hence, the $\mathrm{pH}$ should be maintained for optimal rumen ecology. The rumen $\mathrm{NH}_{3}-\mathrm{N}$ concentration increased in the PTN supplementation groups, while BUN was unchanged. The optimal level of $\mathrm{NH}_{3}-\mathrm{N}$ is from 15 to $30 \mathrm{mg} / \mathrm{dL}$ for rumen fermentation, as revealed by Preston and Leng [34] and Wanapat and Pimpa [35] under a rice straw feeding regime. The TVFA, $\mathrm{C}_{3}$, and $\mathrm{C}_{4}$ were significantly increased, especially in the PTN2 and PTN3 groups, and were the highest, while $C_{2}$ and the $C_{2}: C_{3}$ ratio decreased following PTN supplementation. The reason for this is probably that the buffering agent and CT from PTN sources resulted in enhanced fiber digestion and microbial activity. Similarly, Cruywagen et al. [30] reported that the use of buffering agent from sodium bicarbonate and limestone in the high concentrate diet could increase the total VFA and reduce lactate fermentation. Moreover, $\mathrm{CH}_{4}$ production was consequently decreased by PTN supplementation. This could be the result of the suppression of protozoa and methanogens in the rumen. Similarly, it was found that the use of mangosteen peel pellets and soapberry fruit supplementation containing phytonutrients can influence ruminal fermentation by decreasing the $\mathrm{C}_{2}$ concentration and mitigating $\mathrm{CH}_{4}$ production, thereby increasing the $\mathrm{C}_{3}$ concentration [7]. Wanapat et al. [10] reported that the use of MSP at $100 \mathrm{~g} / \mathrm{d}$ in swamp buffaloes affected the total VFA concentration and increased $\mathrm{C}_{3}$, reducing $\mathrm{C}_{2}: \mathrm{C}_{3}$ and methane production following MSP supplementation. Recently, Shokryzaden et al. [8] and Paengkoum et al. [36] found that condensed tannins (CT) from MSP could reduce methane production by the suppression of ruminal microbes, especially protozoa and methanogens.

\subsection{Rumen Microorganism Population}

The protozoal population was suppressed by supplementation, especially in the PTN1 and PTN3 supplementation groups. This could be due to CT in PTN, which directly react with sterols in the membranes of protozoa. This result was confirmed by Ngamseang et al. [37], who found that the use of MSP containing CT at $150 \mathrm{~g} / \mathrm{d}$ suppressed protozoal population, while supplementation with MSP and soapberry fruit pellets containing CT and SP suppressed protozoal population [7]. Similarly, Shokryazdan et al. [8] additionally stated that replacing alfalfa with $25 \%$ and $50 \%$ MSP mitigated the protozoal population. Polyorach et al. [38] reported, in addition, that MSP supplementation in cows increased the total bacteria concentration, while the protozoal and methanogen populations reduced. Suppression of the rumen protozoal population was found in dairy steers and dairy cows as a result of MSP supplementation [13,37]. Furthermore, Dong et al. [39] revealed that the dietary supplementation of Moringa oleifera containing plant phytonutrients changed the composition and diversity of methanogens and reduced methane emissions in dairy cows. In this study, the fungal zoospore, amylolytic bacteria, and total bacteria concentrations did not differ among treatment groups. However, the cellulolytic bacteria and proteolytic bacteria concentrations increased in the PTN2 and PTN3 supplementation groups. This may be due to the enhancement of the rumen $\mathrm{pH}$ by BFP supplementation [16]. This result was confirmed by Kang and Wanapat [27], who used BFP as a 
rumen $\mathrm{pH}$ buffer, and the results revealed an increase in the rumen $\mathrm{pH}$, as BFP constitutes a high level of minerals, especially $\mathrm{Ca}, \mathrm{Mg}$, and $\mathrm{K}$, and the use of BFP could increase nutrient digestibility and improve rumen fermentation in the ruminants.

\section{Conclusions}

Some source of phytonutrients (PTN) can significantly improve fiber digestibility, bacterial population (proteolytic and cellulolytic bacteria) concentrations, and rumen VFA, especially through an enhanced $\mathrm{C}_{3}$ concentration and, consequently, reduced $\mathrm{CH}_{4}$ production. This study suggests that PTN3 containing either mangosteen peel powder (MSP) or banana flower powder (BFP) could be recommended as a rumen modifier to enhance the rumen fermentation efficiency without negatively affecting feed consumption or the rumen fermentation process.

Author Contributions: T.A. conceived the trial, conducted the feeding experiment, drafted the initial manuscript, and conducted the lab analyses; M.W. generated the design of the study and conducted all statistical analyses, including animal training and animal data collection; K.P. carried out animal data collection and drafted the initial manuscript. All authors read the manuscript, participated in revisions, and approved the final manuscript.

Funding: This research was funded by the Thailand Research Fund (TRF) through the International Research Network (IRN) program (TRF-IRN57W0002 and TRF-IRG598001).

Acknowledgments: Special thanks are extended to the Tropical Feed Resources Research and Development Center (TROFREC), Department of Animal Science, Faculty of Agriculture, Khon Kaen University, Khon Kaen, Thailand and the Thailand Research Fund (TRF) through the International Research Network (IRN) program (TRF-IRN57W0002) and TRF-IRG598001 for their kind support with research funds and the use of their facilities.

Conflicts of Interest: The authors declare that they have no competing conflict of interest.

\section{References}

1. Russell, J.B.; Rychlik, J.L. Factors that alter rumen microbial ecology. Science 2001, 292, 1119-1122. [CrossRef] [PubMed]

2. Wanapat, M.; Chanthakhoun, V.; Wanapat, S. Development of Food- Feed-System for smallholder livestock farmers. In Proceedings of the Animal Nutrition Association World Conferences, New Delhi, India, 14-17 February 2009; pp. 24-27.

3. Bodas, R.; Prieto, N.; García-Gonza'lez, R.; Andre's, S.; Gira'ldez, F.J.; Lo'pez, S. Manipulation of rumen fermentation and methane production with plant secondary metabolites. Anim. Feed Sci. Technol. 2012, 176, 78-93. [CrossRef]

4. Bhatta, R. Reducing enteric methane emission using plant secondary metabolites. In Climate Change Impact on Livestock: Adaptation and Mitigation; Springer: New Delhi, India, 2015; pp. 273-284.

5. Wallace, R.J.; McEvan, N.R.; McIntosh, F.M.; Teferedegne, B.; Newbold, C.J. Natural products as manipulators of rumen fermentation. Asian-Australas. J. Anim. Sci. 2002, 15, 1458-1468. [CrossRef]

6. Kamra, D.N.; Agarwal, N.; Chaudhary, L.C. Manipulation of rumen microbial ecosystem for reducing enteric methane emission in livestock. In Climate Change Impact on Livestock: Adaptation and Mitigation; Springer: New Delhi, India, 2015; pp. 255-272.

7. Poungchompu, O.; Wanapat, M.; Wachirapakorn, C.; Wanapat, S.; Cherdthong, A. Manipulation of ruminal fermentation and methane production by dietary saponins and tannins from mangosteen peel and soapberry fruit. Arch. Anim. Nutr. 2009, 5, 389-400. [CrossRef]

8. Shokryzadan, P.; Rajion, M.A.; Goh, Y.M.; Ishak, I.; Ramlee, M.F.; Faseleh, J.M.; Ebrahimi, M. Mangosteen peel can reduce methane production and rumen biohydrogenation in vitro. S. Afr. J. Anim. Sci. 2016, 46, 419-431. [CrossRef]

9. Guo, Y.Q.; Liu, J.X.; Lu, Y.; Zhu, W.Y.; Denman, S.E.; McSweeney, C.S. Effect of tea saponin on methanogenesis, microbial community structure and expression of mcrA gene, in cultures of rumen microorganisms. Lett. Appl. Microbiol. 2008, 47, 421-426. [CrossRef] [PubMed]

10. Wanapat, M.; Chanthakhoun, V.; Phesatcha, K.; Kang, S. Influence of mangosteen peel powder as a source of plant secondary compounds on rumen microorganisms, volatile fatty acids, methane and microbial protein synthesis in swamp buffaloes. Livest. Sci. 2014, 162, 126-133. [CrossRef] 
11. Oskoueian, E.; Abdullah, E.; Oskoueian, A. Effects of flavonoids on rumen fermentation activity, methane production, and microbial population. BioMed Res. Int. 2013, 8. [CrossRef]

12. Wanapat, M. Rumen manipulation to increase the efficient use of local feed resources and productivity of ruminants in the tropics. Asian-Australas. J. Anim. Sci. 2000, 13, 59-67.

13. Norrapoke, T.; Wanapat, M.; Wanapat, S. Effects of protein level and mangosteen peel pellets (Mago-pel) in concentrate diets on rumen fermentation and milk production in lactating dairy crossbreds. Asian-Australas. J. Anim. Sci. 2012, 25, 971-979. [CrossRef]

14. Foiklang, S.; Wanapat, M.; Norrapoke, T. In vitro rumen fermentation and digestibility of buffaloes as influenced by grape pomace powder and urea treated rice straw supplementation. Anim. Sci. J. 2016, 87, 370-377. [CrossRef] [PubMed]

15. Kang, S.; Wanapat, M. Using plant source as a buffering agent to manipulating rumen fermentation in an in vitro gas production system. Asian-Australas. J. Anim. Sci. 2013, 26, 1424-1436. [CrossRef] [PubMed]

16. Kang, S.; Wanapat, M.; Cherdthong, A. Effect of banana flower powder supplementation as a rumen buffer on rumen fermentation efficiency and nutrient digestibility in dairy steers fed on high concentrate diet. Anim. Feed Sci. Technol. 2014, 196, 32-41. [CrossRef]

17. Association of Official Analytical Chemists (AOAC). Official Methods of Analysis, 19th ed.; AOAC International: Gaithersburg, MD, USA, 2012.

18. Van Soest, P.J.; Robertson, J.B.; Lewis, B.A. Methods for dietary fiber neutral detergent fiber, and nonstarch polysaccharides in relation to animal nutrition. J. Dairy Sci. 1991, 74, 3583-3597. [CrossRef]

19. Wanapat, M.; Gunun, P.; Anantasook, N.; Kang, S. Changes of rumen pH, fermentation and microbial population as influenced by different ratios of roughage (rice straw) to concentrate in dairy steers. J. Agric. Sci. 2014, 152, 675-685. [CrossRef]

20. Burns, R.E. Method for estimation of tannin in the grain sorghum. Agron. J. 1971, 163, 511-512. [CrossRef]

21. Wanapat, M.; Poungchompu, O. Method for Estimation of Tannin by Vanillin-HCL Method (A Modified Method of Burns, 1971); Department of Animal Science, Khon Kaen University: Khon Kaen, Thailand, 2001.

22. Galyean, M. Laboratory Procedure in Animal Nutrition Research; Department of Animal and Range Sciences; New Mexico State University: Las Cruces, NM, USA, 1989; p. 188.

23. Hungate, R.E. A roll tube method for cultivation of strict anaerobes. In Methods in Microbiology; Norris, J.R., Ribbons, D.W., Eds.; Academic Press: New York, NY, USA, 1969; pp. 117-132.

24. Crocker, C.L. Rapid determination of urea nitrogen in serum or plasma without deproteinization. Am. J. Med. Technol. 1967, 33, 361-365.

25. Moss, A.R.; Jouany, J.P.; Newbold, J. Methane production by ruminants: its contribution to global warming. Anim. Res. 2000, 49, 231-253. [CrossRef]

26. SAS (Statistical Analysis System). User's Guide: Statistic, 9.3th ed.; SAS Inst. Inc.: Cary, NC, USA, 2013.

27. Kang, S.; Wanapat, M. Improving ruminal fermentation and nutrient digestibility in dairy steers by banana flower powder-pellet supplementation. Anim. Prod. Sci. 2017, 58, 1246-1252. [CrossRef]

28. Pilajun, R.; Wanapat, M. Effect of coconut oil and mangosteen peel supplementation on ruminal fermentation, microbial protein synthesis in swamp buffaloes. Livest. Sci. 2011, 141, 148-154. [CrossRef]

29. Manasri, N.; Wanapat, M.; Navanukraw, C. Improving rumen fermentation and feed digestibility in cattle by mangosteen peel and garlic pellet supplementation. Livest. Sci. 2012, 148, 291-295. [CrossRef]

30. Cruywagen, C.W.; Taylor, S.; Beya, M.M.; Calitz, T. The effect of buffering dairy cow diets with limestone, calcareous marine algae, or sodium bicarbonate on ruminal $\mathrm{pH}$ profiles, production responses, and rumen fermentation. J. Dairy Sci. 2015, 98, 5506-5514. [CrossRef] [PubMed]

31. Raucha, R.E.; Robinson, P.H.; Erasmus, L.J. Effects of sodium bicarbonate and calcium magnesium carbonate supplementation on performance of high producing dairy cows. Anim. Feed Sci. Technol. 2012, 177, 180-193. [CrossRef]

32. Kang, S.; Wanapat, M.; Viennasay, B. Supplementation of banana flower powder pellet and plant oil sources on in vitro ruminal fermentation, digestibility and methane production. Trop. Anim. Health Prod. 2017, 48, 1673-1678. [CrossRef] [PubMed]

33. Russell, J.B. The importance of $\mathrm{pH}$ in the regulation of ruminal acetate to propionate ratio and methane production in vitro. J. Dairy Sci. 1998, 81, 3222-3230. [CrossRef]

34. Preston, T.R.; Leng, R.A. Matching Ruminant Production Systems with Available Resources in the Tropics and Sub-Tropics; Penambul Books: Armidale, Australia, 1987; p. 265. 
35. Wanapat, M.; Pimpa, O. Effect of ruminal NH3-N levels on ruminal fermentation, purine derivatives, digestibility and rice straw intake in swamp buffaloes. Asian-Australas. J. Anim. Sci. 1999, 12, 904-907. [CrossRef]

36. Paengkoum, P.; Phonmun, T.; Liang, J.B.; Huang, X.D.; Tan, H.Y.; Jahromi, M.F. Molecular weight, protein binding affinity and methane mitigation of condensed tannins from mangosteen-peel (Garcinia mangostana L.). Asian-Australas. J. Anim. Sci. 2015, 28, 1442-1448. [CrossRef]

37. Ngamsaeng, A.; Wanapat, M.; Khampa, S. Effects of mangosteen peel (Garcinia mangostana L.) supplementation on rumen ecology, microbial protein synthesis, digestibility and voluntary feed intake in cattle. Pak. J. Nutr. 2006, 5, 445-452. [CrossRef]

38. Polyorach, S.; Wanapat, M.; Cherdthong, A.; Kang, S. Rumen microorganisms, methane production, and microbial protein synthesis affected by mangosteen peel powder supplement in lactating dairy cows. Trop. Anim. Health Prod. 2016, 48, 593-601. [CrossRef]

39. Dong, L.; Zhang, T.; Diao, Q. Effect of Dietary Supplementation of Moringa Oleifera on the Production Performance and Fecal Methanogenic Community of Lactating Dairy Cows. Animals (Basel) 2019, 9, 262. [CrossRef]

(C) 2019 by the authors. Licensee MDPI, Basel, Switzerland. This article is an open access article distributed under the terms and conditions of the Creative Commons Attribution (CC BY) license (http://creativecommons.org/licenses/by/4.0/). 